\section{Cover Crop Management and Weed Suppression in No-tillage Sweet Corn Production}

\author{
Lidia M. Carrera, ${ }^{1}$ Aref A. Abdul-Baki, and John R. Teasdale \\ Sustainable Agricultural Systems Laboratory, Agricultural Research Service, \\ U.S. Department of Agriculture, Beltsville, MD 20705
}

Additional index words. Zea mays var. 'Silver Queen', hairy vetch, rye, mowing, rolling, herbicides, sustainable agriculture

\begin{abstract}
Cover crops combined with conservation tillage practices can minimize chemical inputs and improve soil quality, soil water-holding capacity, weed suppression and crop yields. No-tillage production of sweet corn (Zea mays var. 'Silver Queen') was studied for 2 years at the USDA BeltsvilleAgricultural Research Center, Md., to determine cover crop management practices that maximize yield and suppress weeds. Cover crop treatments were hairy vetch (Vicia villosa Roth), rye (Secale cereale $\mathbf{L}$.) and hairy vetch mixture, and bare soil (no cover crop). There were three cover crop killing methods: mowing, rolling or contact herbicide paraquat. All plots were treated with or without atrazine and metolachlor after planting. There was a $23 \%$ reduction in sweet corn plant population in the rye-hairy vetch mixture compared to bare soil. Averaged over both years, sweet corn yield in hairy vetch treatments was $43 \%$ greater than in bare soil, whereas yield in the rye-hairy vetch mixture was $30 \%$ greater than in bare soil. There were no significant main effects of kill method or significant interactions between kill method and cover crop on yield. Sweet corn yields were not different for hairy vetch or rye-hairy vetch treatments with or without atrazine and metolachlor. However, yield in bare soil without the herbicides atrazine and metolachor were reduced by $63 \%$ compared to bare soil with these herbicides. When no atrazine and metolachlor were applied, weed biomass was reduced in cover crops compared to the bare soil. Regression analysis showed greater yield loss per unit of weed biomass for bare soil than for the vetch or rye-hairy vetch mixture. This analysis suggests that cover crops increased sweet corn yield in the absence of atrazine and metolachlor not only by reducing weed biomass, but also by increasing the competitiveness of corn to weeds at any given biomass.
\end{abstract}

The economic and environmental advantages of different conservation tillage practices in combination with cover crops have been the subject of many investigations related to the production of field and vegetable crops (Hoyt, 1999; Tracy, 1993; Uri, 2000). Proven advantages of conservation tillage include reduction of soil compaction, erosion, and loss of nutrients as run-off (Karlen, et al., 1990; Stivers and Jackson, 1991; Uri, 2000), retention of soil moisture, increased water infiltration and weed suppression (Tyler et al., 1994; Williams, 1966; Williams and Doneen, 1960), enrichment of soil with organic matter from cover crop residues (Bolton et al., 1985; Tisdall and Oades, 1982), and recycling and $\mathrm{N}$ fixing of nutrients by cover crops (Abdul-Baki et al., 1996; Cline and Silvernail, 2001; Shennan, 1992). The use of cover crops and no-tillage has provided a valuable option for sustainable production systems.

The contribution of $\mathrm{N}$ by cover crops incorporated into the soil has received considerable research efforts. Focus has been directed to the effect of the cover crop (legume versus nonlegume) on the response of the subsequent crop compared to the response to chemical fertilizers.

Received for publication 12 Aug. 2002. Accepted for publication 13 June 2003. This article reports the results of research only. Mention of a proprietary product does not constitute an endorsement or a recommendation by the USDA.

${ }^{1}$ To whom correspondence should be addressed.
Skarphol et al. (1987) found minimal yield differences in snap beans (Phaseolus vulgaris L.) grown using $90 \mathrm{~kg} \mathrm{~N} / \mathrm{ha}$ under conventional tillage versus hairy vetch, crimson clover (Trifolium incarnatum L.), or Austrian winter pea (Pisum sativum L.) incorporated into the soil without additional N. Abdul-Baki and Teasdale (1997) reported a $35 \%$ increase in no-tillage snap bean yield with hairy vetch, compared to bare soil. They attributed the lower yield obtained in bare soil, in part, to soil erosion and nutrient losses induced by heavy rain during the growing season. These studies suggested that no-tillage production using legume cover crops could provide substantial amounts of $\mathrm{N}$ to the subsequent crop and produce commercial yield of snap beans

Table 1. Field operations and evaluations for no-tillage sweet corn production, at Beltsville, Md.

\begin{tabular}{lcc}
\hline & \multicolumn{2}{c}{ Growing season } \\
\cline { 2 - 3 } Operations & 1999 & 2000 \\
\hline Preparing ground and planting cover crops $^{z}$ & 17 Sept. & 4 Oct. \\
Bare soil nitrogen application & 24 May & 25 May \\
Seeding sweet corn & 25 May & 26 May \\
Termination of cover crops & 26 May & 27 May \\
Application of residual herbicide & 7 June & 27 May \\
Corn population determination & 22-29 June & 29 June \\
Application of sidedressing nitrogen & 30 June & 3 July \\
Application of insecticide & Not applicable & 31 July \\
& Not applicable & 4 Aug. \\
Corn biomass collection & 4 Aug. & 3 Aug. \\
Weed biomass collection & 4 Aug. & 3 Aug. \\
First harvest & 20 Aug. & 18 Aug. \\
Second harvest & 27 Aug. & 24 Aug. \\
\hline
\end{tabular}

${ }^{2}$ Dates are for the year preceding the growing season. the herbicide-treated plots yielded significantly more than the untreated plots. Burgos and Talbert (1996) used reduced rates of herbicide in combination with cover crops in no-tillage and conventional sweet corn production in Arkansas and found that rye, wheat, and a mixture of rye and hairy vetch cover crops resulted in $50 \%$ less weeds than when using hairy vetch alone, or using the conventional system. Sweet corn yields in hairy vetch, the conventional system, and the mixture (without chemical weed control) were significantly higher than yields in rye and wheat. They also found that half and full rates of atrazine and metolachlor were equally effective in controlling weeds and produced similar yields regardless of the cover crop used. Yet

with minimal need for commercial fertilizers. Knavel et al. (1977) and Burket et al. (1997) reported a superior yield of sweet corn grown under no-tillage as compared with the conventional system using a commercial $\mathrm{N}$ fertilizer. Burket et al. (1997) estimated the contribution of clover (Trifolium pratense L.) as a cover crop, either alone or in a mixture with rye and pea (Pisum sativum L.), to be $150 \mathrm{~kg} \mathrm{~N} / \mathrm{ha}$. Griffin et al. (2000) compared yields of sweet corn in a conventional system to a no-tillage cover cropping system using alfalfa (Medicago sativa L.), rye, and rye-hairy vetch mixture without additional $\mathrm{N}$, while in the conventional system $\mathrm{N}$ additions of 78 and $156 \mathrm{~kg} \mathrm{~N} / \mathrm{ha}$ were used. Yields were not significantly different between tillage systems; therefore, they concluded that additional $\mathrm{N}$ was not required in the no-tillage system with a legume cover crop.

Covercrops in no-tillage production systems are also used to suppress weeds and, thus, reduce the use of herbicides. Bellinder and Warholic (1988) reported effective weed control and equal yields when using rye as a cover crop and herbicides in no-tillage and conventional tillage production of sweet corn in New York State. Galloway and Weston (1996) reported that hairy vetch cover crop provided higher weed suppression than the other cover crops, with sweet corn yield equal to the conventional tillage treatment in Kentucky. Sweet corn yields were highest in hairy vetch and lowest in ladino clover. The authors attributed the low yields in ladino clover to regrowth and competition of ladino clover with sweet corn. Furthermore, Galloway and Weston (1996) compared weed suppression and sweet corn yields in both systems with and without herbicide and found, within each system, , 
the hairy vetch system and the conventional system resulted in $42 \%$ and $30 \%$ increases in yield over the other cover crops for half and full rate of herbicide used, respectively. These studies suggested that cover crops can offer an effective alternative for weed suppression and reduce herbicide rate usage. No-tillage sweet corn yield differences in these experiments were influenced by geographical location, performance of the winter cover crops, and herbicide rates.

Growth termination of cover crop has been a subject of many studies. In no-tillage production, the cover crops are killed either by the contact herbicides paraquat or glyphosate (N-[phosphono-methyl] glycine) (Bauer and Reeves, 1999; Reeves et al., 1993), or by a mixture of nonselective and residual preemergence herbicides (Teasdale and Shirley, 1998). Sustainable production systems aim at reducing chemical inputs. Thus, mechanical methods for killing cover crops such as, mowing, rolling and roll chopping, undercutting, and partial rototilling have been used. Mowing is commonly used, because the cover crop residues are left as surface mulch (Derpsch et al. 1986; Creamer and Dabney, 2002; Creamer et al., 1995). Rolling and roll-chopping are achieved by breaking, cutting, crushing, or crimping stems (Dabney et al., 1991; Hoffman et al., 1993). Undercutting was developed for raised beds (Creamer et al., 1995). Partial rototilling of living mulch has been used in intercropping systems (Grubinger and Minotti, 1990). The success of any of these methods in cover crop termination depends on the growth stage of the cover crop at the time of killing, the type of cover crop grown, the subsequent crop to be planted, and the cropping system to be used. Cover crop killing methods have also been reported to have an impact on insect populations (Laub and Luna, 1991, 1992), weed emergence (Creamer et al., 1995), and soil temperature (Kaspar and Erbach, 1998).

The objectives of this study were to 1) evaluate the use of cover crops for no-tillage production of sweet corn in Maryland; 2) compare mechanical versus chemical practices for cover crop termination; and 3) assess the influence of cover crops on weed suppression, with and without residual herbicides atrazine and metolachlor.

\section{Materials and Methods}

A 2-year (1999-2000) field study was conducted at USDA Beltsville Agricultural Research Center, Md., on a Matapeake silt loam, with $0 \%$ slope. Weather data were collected at a weather station located $300 \mathrm{~m}$ from the field plot. The experimental design in both years was a split plot design with four replications. Three cover crop treatments (hairy vetch, a rye-hairy vetch mixture, and no cover crop, referred to in this paper as bare soil) were arranged as whole plots in strips across each block. These cover crop strips were split by three cover crop killing methods (mowing, rolling, or contact herbicide paraquat (1, 1'-dimethyl-4, 4'-bipyridinium ion)). A second whole plot, laid out in strips perpendicular to the cover crop was plus or minus the preemergence herbicide mixture of atrazine (6-chloro-N-ethyl-N'-(1-methylethyl)- 1,3,5-triazine-2,4-diamine) plus metolachlor (chloro-N-(2-ethyl-6-methylphenyl)-N-(2-methoxy-1-methylphenyl) acetamide). Each year, the experiment was located on a different site within the same field area. Major field operations are summarized in Table 1. Experimental sites were moldboard-plowed before planting the cover crops. The cover crops were seeded on 17 Sept. 1998, and 4 Oct. 1999. Hairy vetch seed was inoculated with Rhizobium spp.immediately before planting. The seeding rate for hairy vetch when used alone or with rye was $45 \mathrm{~kg} \cdot \mathrm{ha}^{-1}$. The seeding rate for rye also was $45 \mathrm{~kg} \cdot \mathrm{ha}^{-1}$.

Plots without cover crop received $840 \mathrm{~kg} \cdot \mathrm{ha}^{-1}$ of a 10-20-10 fertilizer broadcast by hand before the corn was planted. All plots received 170 $\mathrm{kg} \cdot \mathrm{ha}^{-1}$ of $10-20-10$ fertilizer applied to the furrow at planting time. On 25 May 1999 and 26 May 2000, 'Silver Queen' sweet corn was seeded at target populations of 59,000 (1999) and 54,340 (2000) seeds/ha in 76-cm rows using a no-till seeder (John Deere model 7200; Deere \& Co., Frederick, Md.). Plots were $9.2 \mathrm{~m}$ long and $6.1 \mathrm{~m}$ wide in 1999 and $7.6 \mathrm{~m}$ long and 6.1 $\mathrm{m}$ wide in 2000, with four rows of sweet corn per plot. Cover crops were terminated either mechanically, using a high-speed flail mower (Manufacture Alamo, Seguin, Texas) or roller built by the authors, or chemically, using paraquat at a rate of $0.53 \mathrm{~kg}$ a.i./ha plus $0.25 \%$ nonionic surfactant. The residual herbicides atrazine and metolachlor were applied to designed plots at a rate of $1.1 \mathrm{~kg}$ a.i./ha and $1.4 \mathrm{~kg}$ a.i./ha respectively. The term residual herbicide will be used in this paper to refer to herbicides applied to soil that prevent emergence of weeds after application. Liquid $\mathrm{N}$ (anhydrous ammonia N82) was side-dressed to all plots at a rate of 66 $\mathrm{kg} \cdot \mathrm{ha}^{-1}$ as supplemental N. Thus, a total of 167 $\mathrm{kg} \mathrm{N} / \mathrm{ha}$ was applied to the bare soil treatment, and $83 \mathrm{~kg} \mathrm{~N} / \mathrm{ha}$ was applied to the cover crop treatments, with the balance of $\mathrm{N}$ expected to be supplied by cover crop decomposition. In 2000, the insecticide Asana XL ((s)-cyano(3-phenoxy phenyl) methyl (s)-4-chloro-alpha-(1-methyl ethyl) benzene acetate) was applied twice at a rate of $0.0187 \mathrm{~kg}$ a.i./ha to control corn earworm (Helicoverpa zea Boddie).

Data collection. Cover crop biomass was collected each year $1 \mathrm{~d}$ before seeding the sweet corn. One sample of $1 \mathrm{~m}^{2}$ was randomly taken from each cover crop replication, oven-dried for 1 week at $70{ }^{\circ} \mathrm{C}$, and weighed for determination of biomass. Corn plant population was determined twice in 1999 and once in 2000 from $9.14 \mathrm{~m}$ of all four rows in each plot in 1999 and from $7.62 \mathrm{~m}$ of the two middle rows in each plot in 2000. Random plant samples of ten ear leaves per treatment were collected from $1.3-\mathrm{m}$ lengths on the two inner rows to avoid border effect. Samples within each treatment were oven-dried for 1 week at $70{ }^{\circ} \mathrm{C}$, and ground to pass through a $0.6 \mathrm{~mm}$ mesh sieve for determining nitrogen and carbon contents of tissues using an analyzer (LECO CHN-600 ; Leco Corp., St. Joseph, Mich.). Weed biomass was also determined from a 1.3-m length on both inner rows resulting in a total area of $2 \mathrm{~m}^{2}$ for each treatment. Weed samples were ovendried for 1 week at $70{ }^{\circ} \mathrm{C}$ and weighed. Two sweet corn harvests were performed per year:
20 and 27 Aug. 1999 and 18 and 24 Aug. 2000. Mature ears from a $6.08-\mathrm{m}$ section of the two inner rows were harvested per plot. The total area harvested per plot was $9.24 \mathrm{~m}^{2}$. Number of ears and fresh weight were determined.

Statistical analyses. Data were analyzed using a mixed model analysis of variance (Proc Mixed, SAS Institute Inc., 1999) with cover crop, cover crop killing method, residual herbicide application, and year as fixed effects and blocks and appropriate split plot error terms as random effects. Heterogeneity of variance was modeled by grouping treatments with similar variability. Mean comparisons were generated using the Bonferroni $t$ test with an adjusted $\mathrm{P}$ value. Regression analysis was used to analyze yield data as a function of weed biomass, with cover crop included as a class variable to test for homogeneity of slope between cover crop treatments.

\section{Results and Discussion}

Rainfall and irrigation. Distribution and amount of rainfall differed between the two years of the study. During the growing season, $279 \mathrm{~mm}$ of rain plus irrigation were recorded for 1999, while $396 \mathrm{~mm}$ of rain were recorded for 2000. Below-average rainfall during the growing season particularly during pollination and kernels fill occurred in 1999. In total, 75 mm of irrigation water was applied once before planting and three times later in the season to supplement the crop needs. The rainfall distribution pattern was uniform for 2000 , but scattered for 1999 (Fig. 1). Impact of rainfall fluctuations on cover crop growth and decomposition as well as on corn $\mathrm{N}$ uptake has been reported (Clark et al., 1997a, 1997b).

Corn growth and yield. Sweet corn population was significantly affected by the three-way interaction between covercropby killing method by year (Table 2). Sweet corn plant population was significantly reduced in the rye-hairy vetch mixture compared to hairy vetch alone regardless of kill method or year (Fig. 2). The plant populations were similar in the hairy vetch and bare soil treatments in all situations. In 1999 and in 2000 , the rye-hairy vetch mixture produced $27 \%$ and $32 \%$, respectively, more residue than hairy vetch alone. This dense residue on the soil surface probably did not allow adequate seed-soil contact. Previous research with sweet corn by Cline and Silvernail (2002), Petersen et al. (1986), and Rutledge (1999) has shown plant population reduction when using a cover crop mixture.

Sweet corn yields were significantly affected by four two-way interactions: cover crop by year, residual herbicide by year, residual herbicide by cover crop, and killing method by residual herbicide (Table 2 ). The cover crop by year interaction showed sweet corn yields produced in hairy vetch treatments were significantly greater than those in the other treatments in 2000 but not in 1999 , although the same trend was evident in 1999(Fig. 3). Over both years, hairy vetch increased corn yield by an average of $43 \%$ over bare soil whereas, rye-hairy vetch mixture increased yield by $30 \%$ over bare soil (Fig. 3). Reduced N availability may explain the lower yields in bare soil, since 


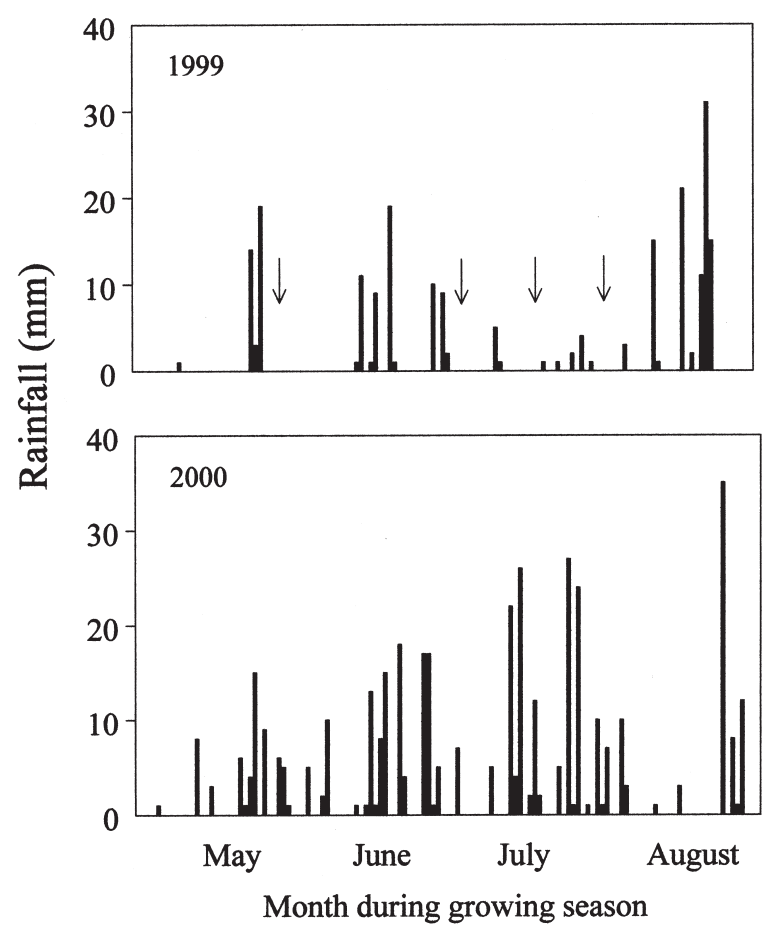

$\mathrm{N}$ content of ear-leaves taken at the silking stage was significantly higher in cover crops than in bare soil. Mean N concentration of corn leaves produced in hairy vetch, rye-hairy vetch mixture and bare soil treatments were $2.6 \%, 2.5 \%$, and $2.1 \%$, respectively. Nitrogen levels in cover crops were within the sufficiency range reported by Reuter and Robinson (1986). Rainfall could have contributed to high $\mathrm{N}$ leaching in bare soil because more $\mathrm{N}$ would be available for leaching in bare soil that is fertilized with inorganic $\mathrm{N}$ than in cover crop treatment with organic $\mathrm{N}$. Cover crop mineralization may have allowed for slow release of $\mathrm{N}$ and more efficient absorption by the sweet corn plants. Also, cover crops are known to influence water retention and water availability. Clark et al. (1997b) reported higher field corn yield in hairy vetch cover crop due to the
Fig. 1. Rainfall during the sweet corn growing season at Beltsville in years 1999 and 2000. Arrowsindicated dates of irrigation ( $25 \mathrm{~mm}$ each time).

summer soil waterconservation by the cover crop. Likewise, Sullivan et al. (1991) reported increases in soil watercontent by increasing the level of cover crop residue.

Since the objectives of the paper focus on the performance of covercrops, interactions that do not involve cover crops will not be discussed in detail. The treatment effect of residual herbicide by killing practice interaction indicated that when residual herbicide was applied, there were no yield differences between killing treatments whereas, without residual herbicides, lower yield was obtained by mowing than by killing with paraquat or rolling (data not shown). Greater regrowth of weeds that were already present at the time of planting in the mowing treatment accounted for lower yield of this treatment without residual herbicide. The treatment effect of residual herbicide by year interaction showed greater yields with residual herbicide than without residual herbicide in both years, but to a greater degree in 1999 than in 2000 (data not shown).

Covercropbyresidualherbicide effects. Yield with residual herbicide application was not different from that without residual herbicides when sweet corn was grown in a vetch or rye-hairy vetch mixture covercrop(Fig. 4). However, sweet corn yield was reduced by $63 \%$ when grown in bare soil without than with a residual herbicide. These results agree with those of Galloway and Weston (1996), who reported no reduction in sweet corn yield due to weed pressure in hairy vetch cover crop treatments.
There was a significant treatment effect of cover crop by residual herbicide interaction for weed biomass (Table 2). Weed biomass was significantly higher in bare soil than in cover crops without residual herbicide, but was low in all treatments with residual herbicide (Fig. 5). Higher weed biomass in the bare soil treatment without residual herbicide can explain the lower yield in this treatment. Weed biomass was probably lower in the cover crop treatments because cover crop residue has been shown to suppress and delay weed emergence, thus giving sweet corn a competitive advantage (Teasdale and Rosecrance, 2003).

Further analysis of yield as a function of weed biomass showed a significant reduction in yield with increasing weed biomass across all cover crop treatments in 1999 and for the mixture and bare soil treatment in 2000 (Figs. 6 and 7). There were no significant differences in slopes among cover crops and bare soil in 1999, but there was a trend for the slope of the regression line to be steeper for bare soil (Fig. 6). In 2000, the regression analysis for comparison of slopes showed significantly steeper slope for bare soil than for the rye-hairy vetch mixture (Fig. 7). This analysis suggests that cover crops increased sweet corn yield in the absence of residual herbicide not only by reducing weed biomass, but also by increasing the competitiveness of corn to weeds at any given biomass. This could be explained by an improved capture of nutrients and water in cover crop systems (Clark et al. 1995).

In summary, we have shown that sweet corn production under a no-tillage system with cover crops can minimize herbicide input, as well as provide the well-known benefits of conserving soil and improving water availability (Clark etal. 1995). Sweet corn yields in hairy vetch residues were significantly higher than in bare soil. Plant population was reduced by approximately $23 \%$ by the rye-hairy vetch mixture but this reduction was not sufficient to significantly reduce yield compared to hairy vetch alone. Greater

Table 2. Analysis of variance combined over 2 years (1999 and 2000) for sweet corn population, sweet corn yield, and weed biomass at Beltsville, Md.

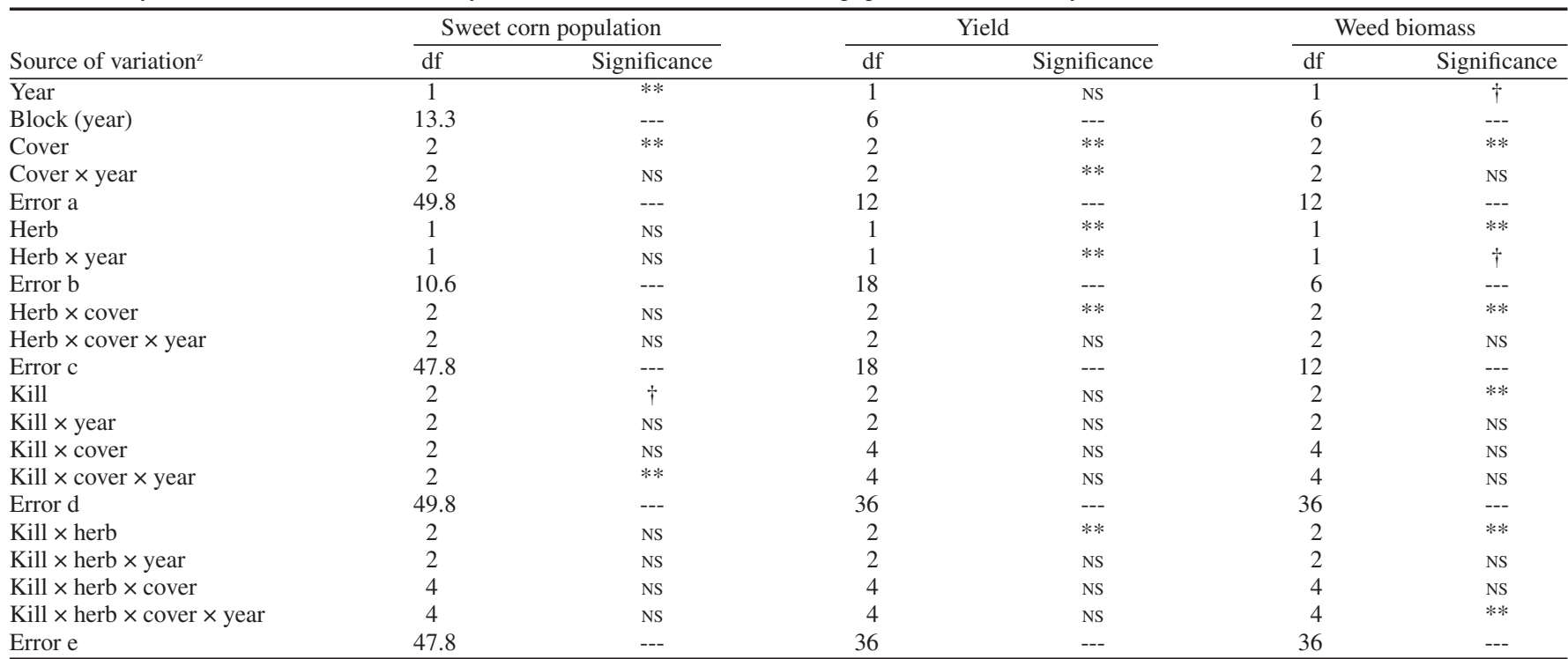

${ }^{2}$ Cover $=$ cover crop, herb $=$ residual herbicide, kill $=$ cover crop killing method.

$\dagger, *, * *$ Significant at $P=0.10,0.05$, or 0.01 , respectively. 


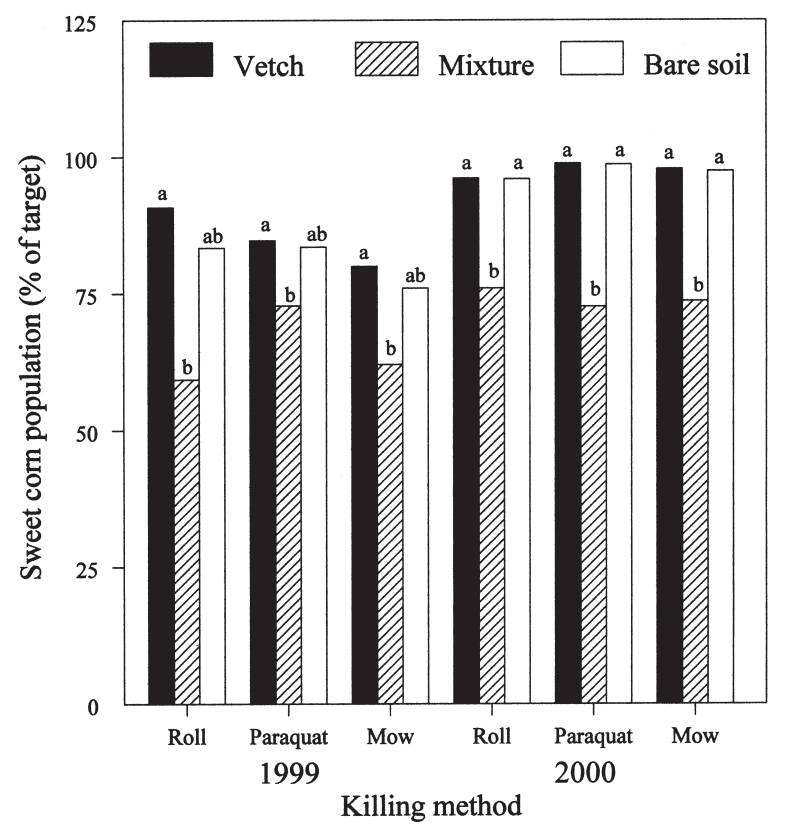

Fig. 2. Sweet corn plant population as affected by hairy vetch, rye-hairy vetch mixture, or bare soil when killed by rolling, mowing, or paraquat in 1999 and 2000. Bars associated with the same letter within kill method and year are not significantly different $(P \leq 0.05)$.

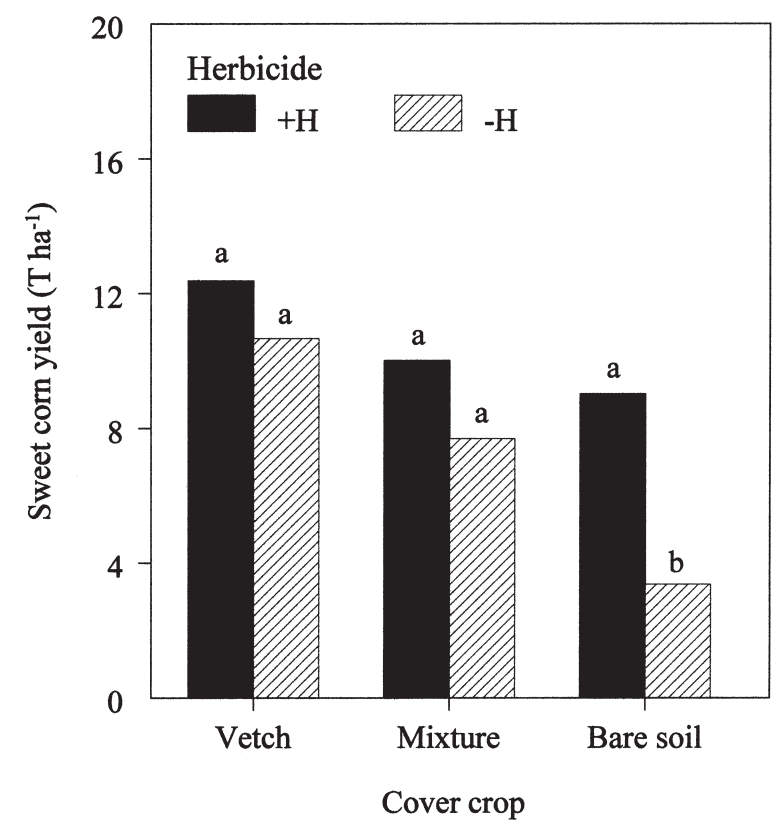

Fig. 4. Sweetcorn yield as affected by hairy vetch, rye-hairy vetch mixture, or bare soil and residual herbicide. Bars associated with the same letter within cover crop are not significantly different $(P \leq 0.05)$.

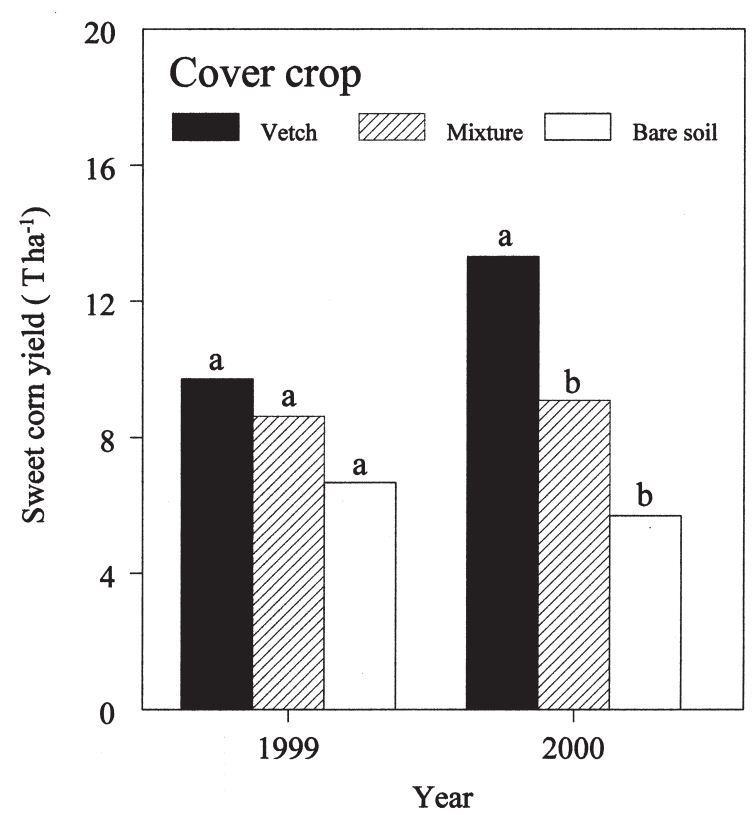

Fig. 3. Sweet corn yield as affected by hairy vetch, rye-hairy vetch mixture, or bare soil in 1999 and 2000. Bars associated with the same letter within year are not significantly different $(P \leq 0.05)$.

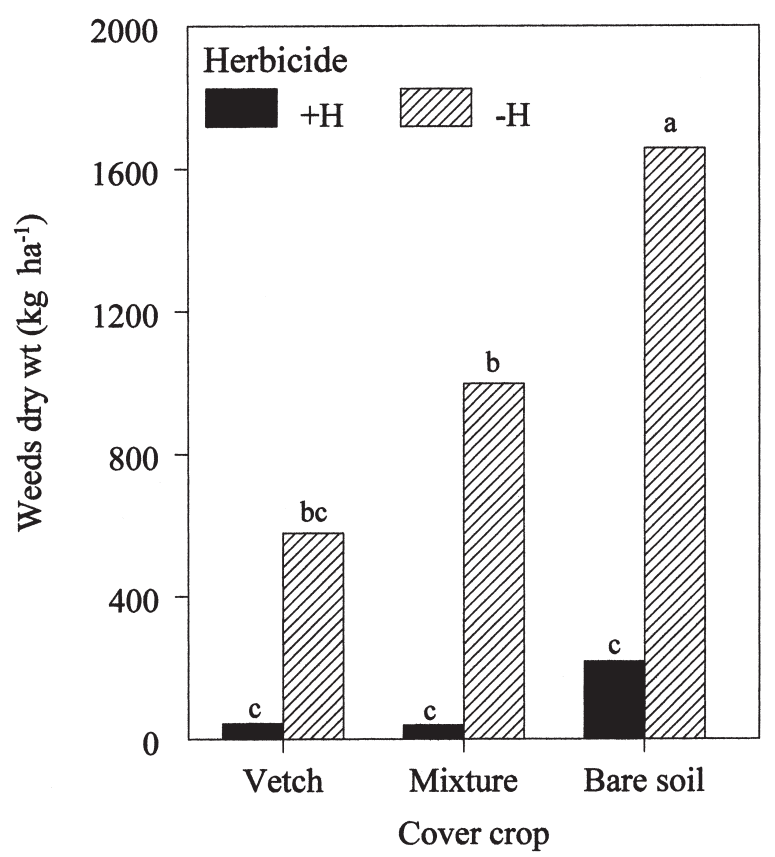

Fig. 5. Weed biomass as affected by hairy vetch, rye-hairy vetch mixture, or bare soil and residual herbicide. Bars associated with the same letter among cover crops are not significantly different $(P \leq 0.05)$. weed suppression was achieved by hairy vetch and rye-hairy vetch mixture than by bare soil. No consistent or significant differences were found between the mechanical and the chemical methods for killing cover crops. Thus, a cover cropping system that includes mechanical kill and eliminates residual herbicides can minimize herbicide input and provide a suitable alternative for sweet corn production in a no-till sustainable production system.

\section{Literature Cited}

Abdul-Baki, A.A. and J.R. Teasdale. 1997. Snap bean production in conventional tillage and in no-till hairy vetch mulch. HortScience 32:1191-1193.

Abdul-Baki, A.A., J.R. Teasdale, R.F. Korcak, D.J. Chitwood, and R.N. Huettel. 1996 Fresh market tomato production in a low input alternative system using cover crop mulch. HortScience 31:65-69.

Bauer, P.J. and D.W. Reeves. 1999. A comparison of winter cereal species and planting dates as residue cover for cotton grown with conservation tillage. Crop Sci. 39:1824-1830.

Bellinder, R.R. and D.T. Warholic. 1988. Comparison of five herbicide programs forno-tillage sweetcorn. Proc. Annu. Meeting N.E. Weed. Sci. Soc. College Park, Md. The Soc. 42:216-220.
Bolton, H., L.F. Elliott, R.I. Papendick, and D.F. Bezdicek. 1985. Soil microbial biomass and selected soil enzyme activities: Effect of fertilization and cropping practices. Soil Biol. Biochem. 17:297-302.

Burgos, N.R., and R.E., Talbert. 1996. Weed control and sweet corn (Zea mays var rugosa) response in a no-till system with cover crops. Weed Sci. 44:355-361.

Burket, J.Z., D.D. Hemphill, and R.P. Dick. 1997. Winter cover crops and nitrogen management in sweet corn and broccoli rotations. HortScience 32:664-668.

Clark, A.J., A.M. Decker, J.J. Meisinger, and M.S. 


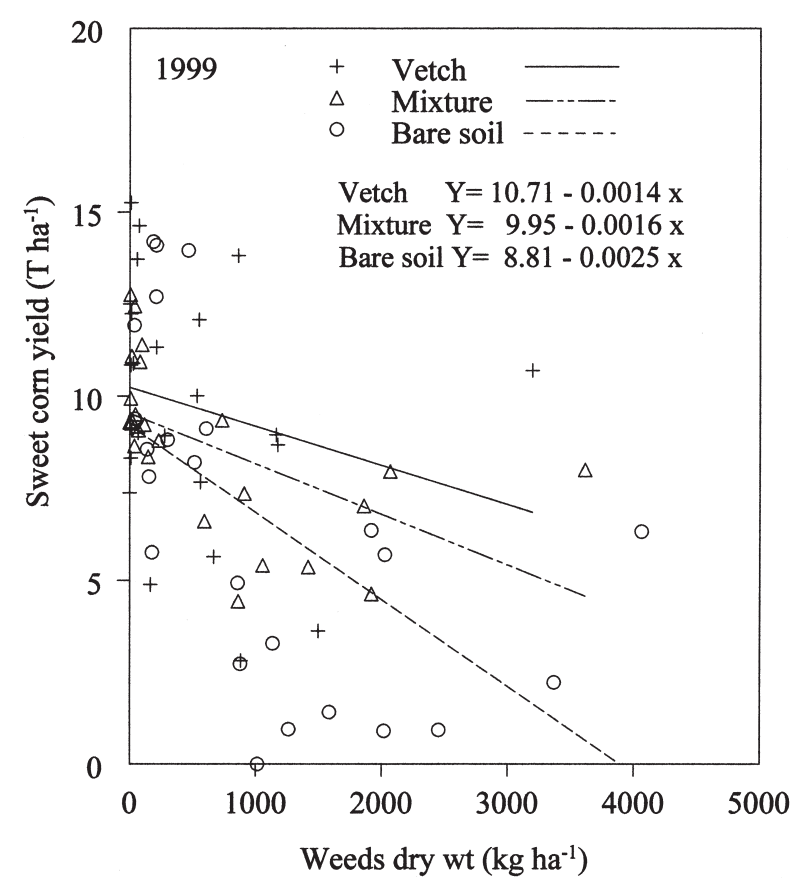

Fig. 6. Regression lines for yield as a function of weed biomass for hairy vetch, rye-hairy vetch mixture, and bare soil in 1999 .

McIntosh. 1997a. Kill date of vetch, rye, and vetch-rye mixture: I. Cover crop and corn nitrogen. Agron. J. 89:427-434.

Clark, A.J., A.M. Decker, J.J. Meisinger, and M.S. McIntosh. 1997b. Kill date of vetch, rye, and vetch-rye mixture: II. Soil moisture and corn yield. Agron. J. 89:434-441

Clark,A.J.,A.M. Decker, J.J. Meisinger, F.R. Mulford, and M.S. McIntosh. 1995. Hairy vetch kill date effects on soil water and corn production. Agron. J. 87:579-585.

Cline, G.R. and A.F. Silvernail. 2002. Effect of cover crops, nitrogen, and tillage on sweet corn. HortTechnology 12:118-125.

Cline, G.R. and A.F. Silvernail. 2001. Residual nitrogen and kill date effects on winter cover crop growth and nitrogen content in a vegetable production system. HortTechnology 11:219-225.

Creamer, N.G. and Dabney, S.M. 2002. Killing cover crops mechanically: Review of recent literature and assessment of new research results. Amer. J. Alt. Agr.17:32-40.

Creamer,N.G.,B.Plassman, M.A.Bennett, R.K.Wood, R.B. Stinner, and J. Cardina. 1995. A method for mechanically killing cover crops to optimize weed suppression. Amer. J. Alt. Agr. 10:157-162.

Dabney, S.M., M.W. Buehring, and D.B. Reginelli. 1991. Mechanical control of legume cover crops, p. 146-147. In: W.L. Hargrove (ed.). Cover crops for clean water. Soil Water Conserv. Soc., Ankeny, Iowa.

Derpsch, R., N. Sidiras, and C.H. Roth. 1986. Results of studies made from 1977 to 1984 to control erosion by cover crops and no-tillage techniques in Paraná, Brazil. Soil Tillage Res. 8:253-263.

Galloway, B.A., and L.A. Weston. 1996. Influence of cover crop and herbicide on weed control and yield in no-till sweet corn (Zea mays L.) and pumpkin (Cucurbita maxima Duch.). Weed Technol. 10:341-346.

Griffin, T., M.Liebman, and J. Jemison, Jr. 2000. Cover crops for sweet corn production in a short-season environment. Agron. J. 92:144-151.

Grubinger, V.P. and P.L. Minotti. 1990. Managing 5:4-12 7:594-599. 41:301-306. 85:98-106. Sydney. 9:366-372.

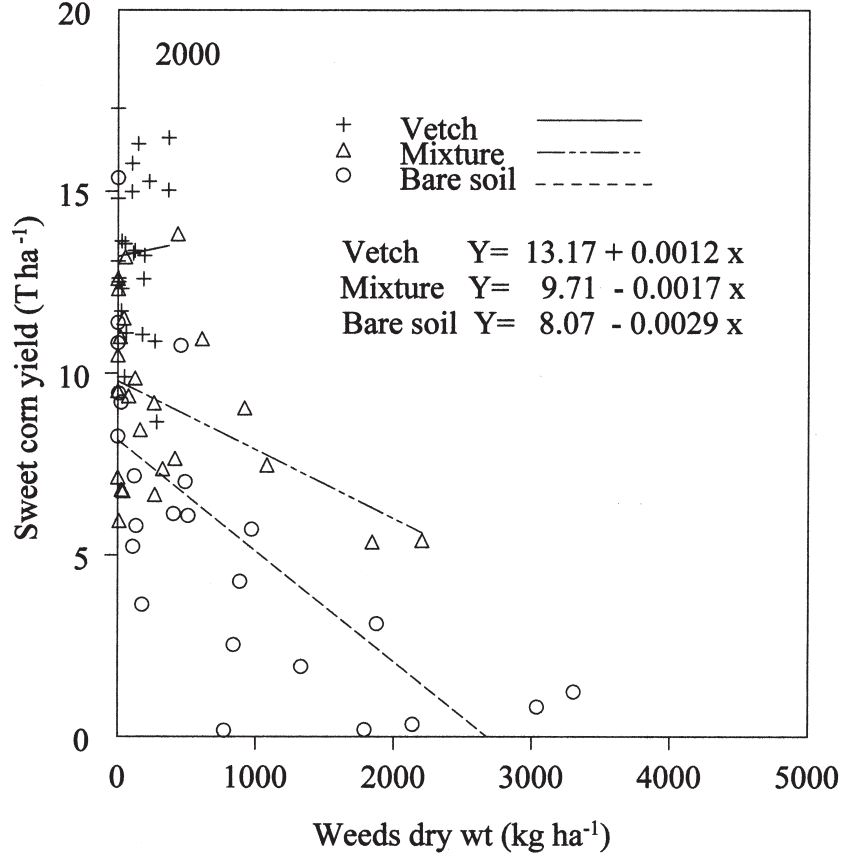

white clover living mulch for sweet corn production with partial rototilling. Amer. J. Alt. Agr.

Hoffman, M.L., E.E. Regnier, and J. Cardina. 1993. Weed and corn (Zeas mays) responses to hairy vetch (Vicia villosa) cover crop. Weed Technol.

Hoyt, G.D. 1999. Tillage and cover residue affects on vegetable yields. HortTechnology 9:351-358.

Karlen, D.L., D.C. Erbach, T.C. Kaspar, T.S. Colvin, E.C. Berry, and D.R. Timmons. 1990. Soil tilth: a review of past perceptions and future needs. Soil Sci. Soc. Amer. J. 54:153-161.

Kaspar, T.C. and D.C. Erbach. 1998. Improving stand establishment in no-till with residue-clearing planter attachments. Trans. Amer. Soc. Agr. Eng.

Knavel, D.E., J. Ellis, and J. Morrison. 1977. The effects of tillage systems on the performance and elemental absorption by selected vegetable crops. J. Amer. Soc. Hort. Sci. 102:323-327.

Laub, C.A. and J.M. Luna. 1991. Influence of winter cover crop suppression practices on seasonal abundance of armyworm (Lepidoptera: Noctuidae), cover crop regrowth, and yield in no-till corn. Environ. Entomol. 20:749-754.

Laub, C.A. and J.M. Luna. 1992. Winter cover crop suppression practices and natural enemies of armyworm (Lepidoptera: Noctuidae) in no-till corn. Environ. Entomol. 21:41-49.

Petersen, K. L., H. J. Mack, and D. E. Booster. 1986. Effect of tillage on sweet corn development and yield. J. Amer. Soc. Hort. Sci. 111:39-42.

Reeves, D.W., C.W. Wood, and J.T. Touchton. 1993. Timing nitrogen applications for corn in a winter legume conservation-tillage system. Agron. J.

Reuter D.J. and J.B. Robinson. 1986. Plant analysis an interpretation manual. Inkata Press, Melbourne,

Rutledge, A.D. 1999. Experiences with conservation tillage vegetables in Tennessee. HortTechnology

SAS Institute Inc. 1999. SAS/STAT user's guide. version 8. vol. 2. SAS, Cary, N.C.

Shennan, C. 1992. Cover crops, nitrogen cycling, and soil properties in semi-irrigated vegetable production systems. HortScience 27:749-754.
Fig. 7. Regression lines for yield as a function of weed biomass for hairy vetch, rye-hairy vetch mixture, and bare soil in 2000. Regression of yield on weed biomass for hairy vetch was not significant, because of insufficient range of weed biomass values.

Skarphol, B.J., K.A. Corey, and J.J. Meisinger. 1987. Response of snap beans to tillage and cover crop combinations. J. Amer. Soc. Hort. Sci. 112:936-941.

Stivers, L.J.and L.E. Jackson. 1991. Winter cover crops to improve nitrogen cycling in the Salinas Valley. Calif. Chapter Amer. Soc. Agron., Proc. 1991 Calif. Plant Soil Conf., San Luis Obispo, 31 Jan.-1 Feb. 1991.

Sullivan, P.G., D.J. Parish, and J.M. Luna. 1991 Cover crop contributions to $\mathrm{N}$ supply and water conservation in corn production. Amer. J. Alt. Agr. 6:106-113.

Teasdale, J.R. and R.C. Rosecrance. 2003. Mechanical versus herbicidal strategies for killing a hairy vetch cover crop and controlling weeds in minimum-tillage corn production. Amer. J. Alt. Agr. 18(2):95-102.

Teasdale, J.R. and D.W. Shirley. 1998. Influence of herbicide application timing on corn production in a hairy vetch cover crop. J. Prod. Agr. 11:121-125

Tisdall, J.M. and J.M. Oades 1982. Organic matter and water stable aggregates in soils. J. Soil Sci. 33:141-163.

Tracy, M. 1993. Food and agriculture in a market economy. Agricultural policy studies. La Hutte, Belgium.

Tyler, D.D., M.D. Mullen, and B.N. Duck. 1994. Soil management research in Tennessee. Tenn. Farm Home Sci. 172:10-13.

Uri, N.D. 2000. Conservation tillage in U.S. Agriculture: Environmental, economic, and policy issues, p. 125. Food Products Press, The Haworth Press, Inc.

Williams, W.A. 1966. Management of nonleguminous green manures and crop residues to improve the infiltration rate of an irrigated soil. Soil Sci. Soc.

Williams, W.A. and L.D. Doneen. 1960. Field studies with green manures and crop residues on irrigated soils. Soil Sci. Amer. Proc. 24:58-61. Amer. Proc. 30:631-634. 